\title{
RULES OF. NOMENCLATURE
}

SIR,--My letter on clause 54 (1) (a) of the "Copenhagen Decisions" (Geol. Mag., 1954, xci, p. 174) was not written without previous discussion with other workers, all of whom agreed with my view, and I have since had letters of support from institutions and individuals as far apart as the United States and New Zealand. Dr. Sabrosky (Geol. Mag., 1954, xci, p. 325) is the first to suggest that we have " misread the decision and misjudged its effects".

This contention appears to me to be quite untenable, for the decision taken by the Copenhagen Congress at the outset of its revision of the Articles of the Code relating to family names, namely the decision to revoke the existing Articles 4 and 5 (1953, Copenhagen Decisions on Zoological Nomenclature, page 32 , decision 43 ) can only mean that the new provisions then adopted apply to all family names, irrespective of the date on which they were published. I therefore cannot accept Dr. Sabrosky's assertion that we have misjudged the effects of the Copenhagen decision.

Apart from this, clause 54 (1) $(a)$ seems to me to be wrong in principle, for it states as a Rule that wrong names are to be used in preference to correct ones. We all recognize that any rules must at times produce an unfortunate result in particular cases, and that such cases should be adjusted by a special act of the Commission under its plenary powers. No limit has been set to the number of such cases that may be brought forward for individual legislation. It is not, however, the correctly formed names that should be suppressed by Rule and require this protection to survive, but the nomenclaturally incorrect names, i.e. those formed on junior synonyms. As remarked in my previous letter, the Rule should state the obvious, which is that the name of a family is to be formed on the valid name of its type genus.

SedGWick Museum,

W. J. Arkell.

CAMBRIDGE.

September, 1954.

\section{THE MIOCENE/OLIGOCENE BOUNDARY IN THE CARIBBEAN REGION}

SIR,--The paper by F. E. Eames in this Magazine (vol. xc, No. 6, December, 1953), and the subsequent exchange of opinions between Drs. Eames and Stainforth (vol. xci, Nos. 2 and 4), are of unusual interest to students of Caribbean stratigraphy.

Eames certainly demands drastic changes in the Upper Tertiary stratigraphy of the Caribbean region but there is no sense in trying to shirk the issue at stake. We are not in a position to contradict his contentions but it seems prudent and scientific to consider seriously his conclusions. Is it only a coincidence that almost all specialists in larger foraminifera with intimate knowledge of faunal assemblages in Europe, North Africa, and the Near and Far East, were, and seemingly still are, inclined to attribute a younger age to post-Eocene larger foraminifera from the Caribbean region than is admitted by their colleagues in the Americas? Why the common reference of students of smaller foraminifera to the close relationship of MiocenePliocene assemblages of the Indo-Pacific with Oligocene ones of the Caribbean region? In the Paleocene and Eocene we accept without hesitation the fact that pelagic forms may be used as universal time markers. There is, therefore, no reason why the same or related genera should not have the same stratigraphic value in younger beds. At least until the end of the Oligocene there was free connection between Atlantic and Pacific provinces across the Darian isthmus (Woodring, 1954, p. 728). This being the case there was nothing to stop free interchange between the two areas at this period, let 
alone between North Africa and the Caribbean region. It is, therefore, necessary to heed the advice of Eames and review and assess the palaeontological evidence of the Caribbean region without preconceived ideas.

Above all we have to agree with Eames who states that the type locality of the Aquitanian must be in the Aquitaine and nowhere else. Secondly, we must reconcile ourselves to the fact that European Tertiary stages are established essentially on the study of shallow water marine molluscs and therefore must disagree with Gignoux $(1936$, p. 503), who--though tentatively only-places the Aquitanian in the Upper Oligocene on account of the Stampian aspect of a mammalian fauna of the lacustrine facies equivalent of the marine type section. Following from these two suppositions we have to place the Aquitanian in the Lower Miocene (see Rutsch, 1952, p. 354), as in fact is done by the U.S. Geol. Survey (Woodring, 1943, p. 1714). Many of the discrepancies found in attempts to make a worldwide correlation of the Upper Tertiary would disappear if universal agreement could be reached on this point.

The boundary between Oligocene and Miocene in Trinidad has recently been discussed (Kugler, 1953, p. 46), when it was pointed out that, in reality, the zone of Globorotalia fohsi belongs in the Lower Miocene and not in the Upper Oligocene as under the present classification used in the Island. If, however, "the evolutionary succession of Miogypsina sensu stricto lies entirely within the Miocene" (Eames, 1954, p. 327), ${ }^{1}$ then hardly any sediments occurring in Trinidad could be assigned to the Oligocene, for in such case the Globigerinatella insueta, the Globigerina dissimilis, and the Globigerina cf. concinna zones would be of Miocene age. The Globigerina cf. concinna zone includes the oldest Miogypsina s. str. bearing sediments in Trinidad and at its type locality contains a rich orbitoid fauna (Stainforth, 1948, p. 1310). Although no Miogypsinae are recorded from the calcareous silts of the type locality, Vaughan and Cole (1941) report Miogypsina hawkinsi and gunteri from eleven different localities of lithothamnia limestone and interbedded marls with the same, or a very closely related, orbitoid fauna characterized by the Lepidocyclina gigas, undosa, favosa assemblage. From three of these localities (Kapur, Morne Diablo, and Mejias) Drooger (1952) reports Miogypsina basraensis, tani, and bronnimanni. Tobler (1925) mentioned Miogypsina from Mejias and Erin Point in association with the above mentioned large Lepidocyclinae and attributed an Upper Oligocene (Aquitanian) age to this assemblage. Whereas the Orbitoid fauna of the type locality of the Globigerina cf. concinna zone occurs in situ, all other post-Eocene occurrences mentioned from Trinidad are from slipmasses embedded with other allochthonous material in the Globigerina dissimilis, Globigerinatella insueta, and Globorotalia fohsi zones and even in the Karamat and Cruse formations. Trinidad is, therefore, not suitable for the study of the lineage of Miogypsinae. Antigua would serve this purpose better.

W. P. Woodring, in his classical study of the Bowden formation in Jamaica, considered the fauna to belong to the Vindobonian stage, or in terms of American stratigraphy, to the top of the Middle Miocene or to the base of the Upper Miocene. P. Bronnimann studied the foraminifera of ten samples from the type locality and in a private report assigned all of them to the Globorotalia mayeri zone which is confined to the Lower Lengua formation of Trinidad and to a basal subzone of it which is known from Trinidad to occur at the base of the Tamana limestone formation. On this information one would expect the Middle and Lower Miocene to be represented by those Tertiary sediments that are found in normal sequence of several thousand feet thickness below the Lengua formation.

The Globorotalia fohsi Zone of the Cipero Formation unconformably underlies the Globorotalia mayeri zone. The neritic facies of the Globorotalia fohsi zone includes the Brasso Formation with a molluscan fauna which has been assigned to the Miocene by Guppy, Mansfield, Maury, and others.

1 Again indirectly suggested by Drooger (1954, p. 246). 
Orbulina, the Miocene marker, does not occur below the fohsi zone. The Pleurophopsis-Thyasira fauna mentioned by Stainforth (1948, p. 1311) from Freeman's Bay, and placed by him in the Globorotalia fohsi zone, occurs in thin, nodular, calcareous mudstones and lenses of cavernous limestones, both embedded in calcareous clays of the Globorotalia mayeri zone of the Lengua Formation. There is no evidence that these coldwater bivalves are allochthonous, although the Lower Lengua Formation is known to carry submarine slipmasses and rubble of older Cipero beds.

The Globigerinatella insueta Zone of the Cipero Formation follows below the fohsi zone and in its shallow water facies is characterized by the reefal limestones of Ste. Croix and the Esmeralda calcareous silt member of the Brasso Formation. Rutsch (1934) studied the pteropods of these beds and pointed to their evident relationship to the Italian Burdigalian (Langhian) and Helvetian. ${ }^{1}$ Schilder (1939), who studied the Cypraeaceae of the Adivinanza quarry (an impure limestone near the Ste Croix limestone and of the same age), attributes a Burdigalian age to them. The corals of these two reefs were considered to be Miocene by Vaughan and Hoffmeister.

The Globigerina dissimilis Zone of the Cipero Formation follows normally below the insueta zone with the Nariva Formation representing its muddy fore deep facies. The dissimilis zone is commonly contaminated with allochthonous material produced by submarine land-slides and turbidity flows. The Lepidocyclina gigas, undosa, favosa assemblage of orbitoids occurs together with Miogypsina in the limestone of Kapur, which, according to Bronnimann (private report) and Drooger (1952, p. 21), represents a shallow water facies of the Globigerina dissimilis zone. However, at this locality this zone also carries reworked material of Upper Eocene and Middle Eocene age, as well as foraminifera of the Globigerina cf. concinna zone.

Miogypsina complanata is reported by Drooger (1951, p. 363) from Trinidad. According to Bronnimann (private report) this form occurs in the Globigerina dissimilis zone and Caudri (in Stainforth, 1948, p. 1312) reports it from the limestone and marl of Mejias Quarry. The Mejias limestone slipmass is found embedded in the Globigerina fohsi zone.

The Globigerina cf. concinna Zone ${ }^{2}$ follows normally below the dissimilis zone and, as already mentioned, at the type locality carries an orbitoid fauna of the Lepidocyclina gigas, undosa, favosa assemblage which Vaughan and Cole (1941, p. 28) consider to be of Upper rather than Lower Oligocene age. The poor molluscan fauna of seven species was studied by Rutsch (Stainforth, 1948, p. 1310) and the age was determined tentatively as either Rupelian or Chattian. The most common species is Propeamussium bronni pennyi (Harris) which is also found in younger beds. In addition, J. W. Wells (private letter) mentions the coral Trochocyathus (Aplocyathus) obesus (Michelotti) from the type locality. The orbitoid fauna of the type locality shows great similarity in composition to that of Mejias, Kapur, and other limestone slipmasses of South Trinidad. This assemblage is closely related to that of the type locality of the Antigua limestone in Antigua and the San Luis limestone in the State of Falcon (Venezuela). J. W. Wells who studied the coral fauna of the Antigua limestone mentions in a private letter thirtythree different species. Of these he noted six species amongst the fourteen listed from Kapur Quarry. Three of the species from Kapur also occur amongst the twenty-five species of the San Luis limestone. The coral fauna of Antigua is considered to be Oligocene. The Antigua limestone rests unconformably on stratified tuffs with cherts bearing a typical fresh-water molluscan fauna and beautifully preserved silicified wood of a comparatively rich flora. At San Fernando (Trinidad) the orbitoid assemblage of Lepido-

1 Drooger (1954) correlates the "Langhiano" and "Elveziano" of the piedmont area of Turin with the upper part of the Aquitanian of the Bordeaux area.

2 Bolli (1954) described Globigerina cf. concinna as Globigerina ciperoensis and in future the zone has to be called accordingly. 
cyclina gigas, undosa, favosa rests directly on the Upper Eocene (Stainforth, 1948 , p. 1309). In reality, one observes at the type locality of the San Fernando Formation, at Mt. Moriah, well bedded, calcareous, glauconitic sands of Upper Eocene age superimposed on Middle Eocene Navat Formation, Paleocene Chaudiere shale, and Upper Cretaceous Naparima Hill Formation. These glauconitic sands are unconformably overlain by a block conglomerate, about 20 feet thick, dominantly composed of Upper Cretaceous blocks. This conglomerate changes rapidly upwards into sand and silt of apparently Upper Eocene age, including bioherms of Upper Eocene orbitoidal lithothamnia limestone rich in echinids (Echinolampas) and a few molluscs. A few large blocks of Maestrichtian glauconite sand, blocks of Paleocene Soldado Formation and of Senonian Naparima Hill Formation are embedded in these sands and silts. These Upper Eocene beds grade upwards into the Globigerina cf. concinna zone.

Up to now no definite Lower Oligocene sediments have been established in Trinidad, although it is known that foraminiferal calcareous sediments exist between the cf. concinna zone and the Upper Eocene. Similar uncertainties are known from Venezuela where the Guacharaca Formation of the Agna Salada Group (Renz, 1948, p. 30) might belong to it.

There is obviously every reason to expect the presence of sediments of the entire Oligocene time where carbonate deposits were being laid down from Upper Eocene times into the Oligocene.

Woodring (1954, p. 727) states that in the Caribbean region "an early Oligocene part has not yet been faunally defined". It appears that one of the first steps to be taken is to define the age of the Antigua limestone with its rich assemblage of larger foraminifera, corals, echinoids, and a few molluscs. Such definition of age has, however, only a meaning if palaeontologists and stratigraphers can arrive at an agreement regarding the top of the Oligocene and cannot be solved by coining new stage names based on foraminiferal assemblages; a procedure that can only lead to chaos in stratigraphic nomenclature. Agreement has generally been reached as regards the base of the Oligocene inasmuch as the top Eocene pelagic foraminifera are universally widespread and well-defined. The definition of the top of the Oligocene is of sufficiently great importance to deserve the attention of the International Geological Congress and it is hoped that this question may be taken up in 1956. In Mexico, geological conditions for the solution of this problem are amongst the best to be found. A world-wide correlation of Tertiary marine sediments based on pelagic foraminifera is the ardent desire of most micro-paleontologists and geologists.

Until more compelling evidence is available, and the whole matter is discussed at an international meeting, I consider that the base of the Caribbean Miocene should be placed temporarily at the base of the Globorotalia fohsi zone.

H. G. Kugler.

TRINIDAD LEASEHOLDS, LTD.,

PoINTE-A-PierRe, Trinidad.

24 th September, 1954.

\section{REFERENCES}

Beckman, J. P., 1953. Die Foraminiferen der Oceanic Formation (EocaenOligocaen) von Barbados, K1. Antillen. Ecl. Geol. Helv., lxiv, $301-412$.

Bollı, H., 1954. Note on Globigerina concinna Reuss, 1850. Contrib. Cushman Found. Foram. Res., v, 1-3.

COOKe, C. W., J. Gardner, and W. P. WoOdring, 1943. Correlation of the Cenozoic Formations of the Atlantic and Gulf Coastal Plain and the Caribbean Region. Bull. Geol. Soc. Amer., liv, 1713-1724. 
Drooger, C. W., 1951. Notes on some representatives of Miogypsinella. Proc. Konink. Nederl. Akad. Wetensch., liv, 357-365.

1952. Study of American Miogypsinidae. Diss. Utrecht University. 1954. Miogypsina in Northern Italy. Koninkl. Nederl. Akad. Wetensch., Ivii, 228-249.

Gignoux, M., 1936. Géologie stratigraphique. Paris.

Kugler, H. G., 1953. Jurassic to Recent Sedimentary Environments in Trinidad. Bull. Ass. Suisse Géol. et Ing. Petrole, xx, 27-60.

Leriche, M., 1938. Contribution a l'étude des Poissons fossile des pays riverains de la Méditerranée americaine. Mém. Soc. Pal. Suisse, lxi, 1-43.

Renz, H. H., 1948. Stratigraphy and fauna of the Agna Salada Group, State Falcon, Venezuela. Geol. Soc. Amer. Mem., 32.

Rutsch, R. F., 1952. Das Typusprofil des Aquitanien. Ecl. Geol. Helv., xliv, 352-5.

Rutsch, R., 1934. Pteropoden und Heteropoden aus dem Miocaen von Trinidad. Eclog. Geol. Helv., xxvii, 299-326.

Stainforth, R. M., 1948. Description, Correlation, and Paleoecology of Tertiary Cipero Marl Formation, Trinidad, B.W.I. Bull. A.A.P.G., xxxii, 1292-1330.

TOBLER, A., 1925. Miogypsina im untersten Neogen von Trinidad und Borneo. Ecl. Geol. Helv., xix, 719-722.

Vaughan, T. W., and W. S. Cole, 1941. Preliminary Report on the Cretaceous and Tertiary larger Foraminifera of Trinidad, British West Indies. Geol. Soc. Amer. Special Paper No. 30.

Woodring, W. P., 1954. Caribbean Land and Sea Through the Ages, Bull. Geol. Soc. Amer., lxvi, 719-732. 